\title{
The real crisis of the church
}

Author:
Wim Dreyer ${ }^{1}$
Affiliation:
'Faculty of Theology,
University of Pretoria,
South Africa
Correspondence to:
Wim Dreyer
Email:
wim.dreyer@up.ac.za
Postal address:
17 Elephant Road,
Monumentpark, Pretoria
0181, South Africa
Dates:
Received: 15 Sept. 2014
Accepted: 21 Feb. 2015
Published: 21 May 2015
How to cite this article:
Dreyer, W., 2015, 'The
real crisis of the church',
HTS Teologiese Studies/
Theological Studies $71(3)$,
Art. \#2822, 5 pages. http://
dx.doi.org/10.4102/hts.
v71i3.2822
Copyright:
○ 2015. The Authors.
Licensee: AOSIS
OpenJournals. This work is
licensed under the Creative
Commons Attribution
License.

What is the real crisis of the church? Very often, clergy, churches and congregations experience a 'crisis' only when membership is in decline, resulting in financial hardship. Crisis is limited to stress which the church as institution experiences when structures, finance and traditions are under pressure. In this contribution, the point is argued that the real crisis of the church is not to be found in institutional challenges, but in the inability of the church to be what it already is. With reference to Karl Barth's ecclesiology, this contribution departs from the assumption that the real crisis of the church is not only to be found in external circumstances and influences, but is primarily a question of the church not being able to 'be church'. Continued reformation of the church is of utmost importance.

\section{Introduction}

Since World War II, many prominent theologians realised the importance of ecclesiology and, as a result, published substantial monographs on the matter. Mannion and Mudge (2010) start the Routledge Companion to the Christian Church with the following phrase:

The nature, story and study of the Christian church have become very popular areas of inquiry across various religious communities, in courses of theology and religious studies and in the field of scholarly debate ... ecclesiology has become of great topical interest once again. (p. 1)

Veli-Matti Kärkkäinen (2002:7) calls it an 'ecclesiological renaissance'. I suspect that the renewed interest in the church has much to do with a deep sense of crisis.

The 20th century started in a very optimistic mood. Miracles were performed by scientists; automobiles, modern factories, new medicines and aeroplanes left people bedazzled and optimistic. Optimism was tangible at the 1910 World Missionary Conference held in Edinburgh. Spreading the Christian faith to all nations was a goal to strive for and something which could be achieved through hard work and commitment. Since 1910, the mood has changed significantly. Wars, natural disasters, poverty, economic recessions and the misuse of technology made people realise that 'a life in abundance for all' (Jn 10:10) is not a simple matter. Reality is not simple; it is utterly complex and chaotic. It left the church with few answers and little to say.

People of the 20th century experienced the rise and disastrous effect of ideologies such as Fascism, Nazism, Communism, Capitalism and Neoliberalism. In an attempt to retain some semblance of influence and power, the church often gave wrong answers, sided with the wrong people and even supplied theological and ethical justification to injustice and violence. Approximately 231 million people died during the 20th century due to racial, ethnic and military violence (Leitenberg 2006; Scaruffi 2009). Margaret Drabble (2001:160), acclaimed British author, expressed the disillusionment of many in the form of a paper she delivered on 14 December 2000 at the Royal Society of Literature, when she called the 20th century a 'beastly century'.

Many Christians were disillusioned by the church's lack of integrity and perceived servitude to political agendas. In the course of one century, the church became completely marginalised and people started leaving the church in droves (Van't Spijker 1990:507-508). Growing disillusionment and scepticism is one of the features of contemporary society. A quick search on the Internet reveals a vast array of websites by sceptics, for sceptics. Much of what was once regarded as 'holy' is subjected to deconstruction and logic, including the church. Ecclesial optimism disappeared like mist before the sun. This created a sense of crisis and challenged theologians to reflect critically on the nature and calling of the church.

This contribution gives an overview of different theologians' understanding of crisis; it departs from the assumption which Karl Barth already postulated in 1933 that the real crisis of the church is not only to be found in external circumstances and influences but is primarily a question of the 
church not being able to 'be church' (Barth 1933:10-11) and concludes with some remarks on church reformation.

\section{Theological perspectives on the 'church crisis'}

In recent times, theologians all over the world reflected on the church crisis from divergent perspectives. A few examples will illustrate the point.

Gerben Heitink ([1993] 2000, 2007) identifies modernity and the effects of the Enlightenment as reasons for the ecclesial crisis. The crisis had deepened to such an extent that the church finds it almost impossible to witness to the world. Even Practical Theology has become a 'crisis science' (Heitink [1993] 2000:27). In his introduction to Een kerk met karakter (Heitink 2007), he became even more outspoken: at the start of the 21st century the church is in bad shape and if it is not able or willing to undergo a process of radical transformation, the church - as institution - will disappear from Dutch society. The situation has become critical, and the church in Europe is facing its most severe crisis in 20 centuries (Heitink 2007:21).

In the United States of America (USA) people are speaking of an ecclesial crisis which is taking on catastrophic dimensions. D.L. Guder (2000) writes as follows:

The phrase ecclesia reformata secundum verbi Dei semper reformanda is used a great deal in North Atlantic Reformed circles these days, probably because of the crisis in which most of these churches find themselves. (p. 150)

In Approaching the end, Stanley Hauerwas (2013:ix-xi) uses almost apocalyptic language: 'The end that the church is approaching, or at least some churches may be approaching, is quite literally death'. He is of the opinion that institutional Christianity has reached its end. Denominations which seem to be successful in terms of growth are normally those who adapted to the culture of consumerism and marketing. Hauerwas points out that many of these denominations are showing a marked decline in membership and will continue to do so, an opinion shared by Miroslav Volf (1998:6). Hauerwas is very critical of denominations playing the popularity stakes. The price paid for popularity is high, which is loss of integrity and identity. The church is in crisis because it is not church anymore.

\section{Cheryl Peterson (2013) writes:}

We are living in a time when survival is on the mind of most mainline congregations and denominations ... One analyst has forecast that, given certain trends and demographics, my denomination, the Evangelical Lutheran Church in America, will 'turn out the lights' in 2046. (p. 1)

She points out that cultural changes in American society affected the traditional mainline Protestant churches the most, but Pentecostal and so-called 'mega-churches' are also showing a decline in membership. New religious movements tend to be small and intimate. In a postmodern era Christians will probably migrate to communities of faith which foster genuine spirituality, friendship and meaningful relationships (Peterson 2013:3).

Roman Catholic theologians are very much aware of changing realities and a growing sense of crisis; for example, Karl Rahner and Hans Küng played an important role in the formulations adopted in Lumen Gentium during Vatican II (cf. Flannery 1975:350-426), which became instrumental in the renewal of the Roman Catholic Church. Postconciliar publications of individual theologians on ecclesiology continued this trend. During 1976, Küng published his famous Die Kirche; in this he poses the question (Küng 1976:481): 'Has the Church a future?' He is confident that the church, despite the crisis it is facing, will continue with the proclamation of the gospel in accordance with its true nature and calling. In his commentary on the Apostolicum, Küng (1992:172) writes that it is common knowledge that the church of the 20th century is caught up in a 'dramatischen und tiefgreifenden' credibility crisis. The integrity of the church is often questioned. Twenty years later he returns to his question concerning the future of the church (Küng 2003:204) when he argues the point that the church will only survive if it could move past the Enlightenment, Reformation and the Middle Ages to the origins of the church in the early Jesus movement. This does not imply a simplistic idealisation or reduplication of the Jesus movement, rather an identification with the kingdom of God which became manifest with the incarnation of Christ.

It seems different in Africa and Asia. In some areas in Asia (e.g. China and Korea) and in Africa the church is growing. Christianity has become a truly global religion and in every single country in the world the church is present. But even in this context some critical questions need to be answered: is every gathering in the name of God 'church'? Not only in the USA but also in Asia and Africa some 'churches' function as commercial enterprises with huge revenue, generating hundred million dollars in revenue per annum. These churches encapsulate the very essence of materialism (cf. Rah 2009). Much of the revenue is generated from 'healing ministries'. In some cases where patients stopped medical treatment as a result of fraudulent healing ministries, it led to their death (cf. Randi 1987). In some cases where a 'church' seems to be doing quite well, it is actually creating a major crisis in that it destroys the credibility of the gospel and the church.

In South Africa, signs of decline are becoming more and more evident. David Bosch, the well-known South African missiologist, wrote in Transforming missions ([1991] 2006:3-5) about the deepening crisis of the church. Bosch is primarily concerned about the inability of the church to be involved in meaningful missions. In a modern and postmodern society the church finds it increasingly difficult to live missional. Despite this, the church is still challenged by the Great Commission (Mt 28:18-20). A crisis in terms of missions translates into a crisis for the church as such, because the church is not doing what it is supposed to do. The church is unfaithful to its own nature and calling. 
Bart Oberholzer, another South African theologian and former Dean of the Faculty of Theology in Pretoria, also spoke of crisis. He was of the opinion that the growing interest in ecclesiology is something of a confession, an acknowledgement that the church had been busy with many things without really listening to God (Oberholzer 1995:852). Oberholzer emphasises that a new understanding of what it means to 'be church' of the Triune God and a new, simplified model of church has become critically important. People are leaving the church because it got stuck in the 16th century. His criticism grows even stronger when he writes that the new millennium confronts the church with its own failures (Oberholzer 1999:449): the church is in decline, it struggles to survive financially, and theological faculties are closing down. Very often theologians contribute very little to the life of the church. Congregants believe the church belongs to them and, for that specific reason, failure has become inevitable.

Nelus Niemandt (2007:38) is of the same opinion. The church is responsible for its own crisis. Churches are responsible for people leaving the church and the growing number of agnostics. He concludes that the church, in its traditional form, will find it very difficult to survive in a postmodern society. Pete Ward (2002:13) writes as follows: 'The question is whether our churches are part of the problem or part of the solution?'

The phenomenal growth in research in the fields of Congregational Studies and Practical Theology is, to my mind, indicative of pastors and theologians looking for ways and strategies to do things differently and better. Despite all the effort, the crisis only deepens. Frost and Hirsch (2013) write:

When we reflect on the 1990s, the declared Decade of Evangelism, we are given cause for deep concern. For all the flurry and activity across the West, in particular the U.S. and U.K., church members have continued to decline. When once it was assumed that church planting was the strategy of reaching a postmodern West, church-growth experts are now having second thoughts. Church membership had been flagging, and as the Decade of Evangelism proceeded, fewer and fewer churches were being planted. (p. 17)

The church stands embarrassed by its own inability to respond in an appropriate manner to the growing crisis.

Alan Hirsch (2006) continues as follows:

For the vast majority of churches, church growth techniques have not had any significant or lasting effect in halting their decline. Of the 480000 churches in America, only a very small portion of them can be described as successful seeker-sensitive churches, and most of them have fewer than eighty members. What is more, the church in America is in decline in spite of having church growth theory predominating our thinking for the last forty or so years ... It has failed to halt the decline of the church in America and the rest of the Western world. (p. 36)

Kees de Groot (2007:41) pointed out that despite all the research and thousands of publications, very little has changed. A large percentage of ministers and pastors feel their theological education was inadequate, did not prepare them for their role in church and society with the result that many are leaving the ministry which again deepens the crisis. This is a worldwide phenomenon, but specific research in the USA (cf. Stewart 2009) indicates vast numbers of pastors leaving ministry, thus placing ministry as a profession in great jeopardy. A Duke University study found that $85 \%$ of seminary graduates entering the ministry leave within five years and $90 \%$ of all pastors will not stay to retirement. 'Irrelevant' theological education is one of the main reasons for leaving ministry. This is indicative of the crisis many congregations and churches experience and I believe a fundamentally flawed understanding of what it means to be the church of the Triune God.

The different perspectives on the church crisis could be summarised very shortly in a few categories:

- the effects of modernity and the Enlightenment leads to secularisation, loss of faith and scepticism

- declining church membership

- materialism and fraudulent ministry

- inability to witness to the world

- obsolete and irrelevant theology

- the perception that the church could be managed or organised into growth.

\section{The real crisis}

Hendrik Kraemer (1947:24), after the destruction of World War II, wrote that the church had always lived with crisis. Each generation must realise anew that the church will always be ecclesia militans. The church is always the pilgrim church on its way to the New Jerusalem, always in opposition to ideologies and always under threat. However, these external threats and the cross the church has to bear are insignificant compared to the threat from within. Following Karl Barth, Kraemer is of the opinion that the biggest threat to the church is its own inability to 'be church'. In his discussion of Barth's ecclesiology, Eberhard Busch (2004:246-247) comes to the same conclusion: the challenge facing the church is to 'be church' and to 'stay church'. The discrepancy between the true nature and empirical manifestation of the church leads to crisis, loss of integrity and regression.

But what is the real nature of the church then? What is the sanctam Ecclesiam catholicam the Symbolum Apostolicum speaks of? Karl Barth discussed this formulation of the Apostolicum in various publications, often product of his classroom lectures. Barth (1947:5-6) used the Apostolicum as a basis to teach students Dogmatics. The first of these was his Credo which he worked on in 1935 and published a year later (Barth 1936). In 1943, Barth published a French commentary on the Apostolicum, using John Calvin's Instruction et confession de foy (1537) as basis. This was later translated into German by Helmut Goes (Barth 1967) just a year before his death. It is rather remarkable that Barth in his 1947 exposition of the Apostolicum includes credo unam ecclesiam, which of course does not appear in the original text of the Apostolicum but 
comes from the Nicene Creed. In his earlier exposition based on Calvin's Catechism, he does not refer to the unity of the church.

In Barth's exposition of the sanctam Ecclesiam catholicam (1947:187-197) he emphasises the work of the Holy Spirit. It is not without reason that in the text of the Apostolicum the article on the church follows directly after and from credo in Spiritum Sanctum (Busch 2003:240). The Holy Spirit unites people with Jesus Christ. In this continual act of unification between Christ and his body the church becomes visible in the world. The visible church is as such the embodiment of the invisible church (Barth 1947:189). The church manifests in communities (Gemeinde), living a holy life as God's people. Holy, in this sense, has the meaning of a community dedicated to God and distinguishable from other communities or peoples. The distinction does not lie in being without sin, but in the specific calling the church has to proclaim the gospel of Jesus Christ (Barth 1947:191).

Believing the church to be Catholic always remained part of the reformed tradition even though it sometimes creates confusion as if it only refers to the Roman Catholic Church. In its original meaning it refers to the 'whole' church in comparison to 'local' churches (Küng 1992:182). 'Catholic' refers to the one people of God. This people may take on different forms in different times and different contexts, but always remains essentially the people of God. This is so even when there is obvious weakness, wrong ideas and even heresy (Irrtümer - Barth 1947:191) present in the visible church. Barth warns that the question of the true and false church should not be brought under discussion to easily. The visible church will always remain just a preliminary manifestation of God's kingdom (Barth 1967:127). God's kingdom is also not limited to the church (Barth 1967:130).

This does not mean that the visible church is unimportant. Although God's kingdom is more than the church, the church still remains the specific space where Christ is present and is experienced as present. It is a holy space where people pray together as a community of faith (Barth 1967:130-131). In the church, the body of Christ becomes visible. This has very particular implications: we cannot ignore the visible church as if it is enough just to be 'Christian'. We should remain loyal to the church. According to Barth (1967:135), 'Faith is life. Life means labour. Labour means being here and not everywhere. Confessing the church means saying "yes" to a real life and presence in the church'. One can only be a Christian through the proclamation of the church, and therefore being a Christian is never just private business. Because the Holy Spirit unites all in Christ and with each other, being Christian is in essence communal (Busch 1998:246).

If we confess with the Apostolicum the sanctam Ecclesiam catholicam and we understand ourselves as members of the one, holy and Catholic Church, the question is: what does it mean to be holy? Anyone knowledgeable about the history of the church can write books on the criminal deeds committed in the name of the church as well as individual Christians
(Küng 1992:186). The church consists of sinners and the church is sinful, and nothing the church does will change that fact. The holiness of the church and its members is therefore not dependent on what people do, but completely dependent on God's actions. The church is holy through God's grace and the redemptive work of Jesus Christ. Küng (1992:187) reminds us that the church will always remain holy and sinful at the same time, as Luther taught us in his famous simul iustus, simul peccator.

The fact that the church is simul iustus, simul peccator and holy only through the grace of God should not lead us to think that 'anything goes' in terms of being church. In Romans 6:1-5 (English Standard Version), the apostle Paul writes:

What shall we say then? Are we to continue in sin that grace may abound? By no means! How can we who died to sin still live in it? Do you not know that all of us who have been baptized into Christ Jesus were baptized into his death? We were buried therefore with him by baptism into death, in order that, just as Christ was raised from the dead by the glory of the Father, we too might walk in newness of life. For if we have been united with him in a death like his, we shall certainly be united with him in a resurrection like his.

Being baptised into Christ's death and resurrection, being one with Christ through the power of God not only speaks of personal salvation, but is of importance to our understanding of the church. The unity between Christ and the believers which is signified in baptism is fundamental to our understanding of the church. In this passage the implications is spelled out: those who died with Christ and resurrected through the power of God is dead to sin not because we are sinless, but because God made us to be so. The indicative of being holy does not negate the imperative of living holy. The church and individual Christians may never become complacent. If we do not accept that every biblical indicative is followed by an imperative, the church will remain in crisis and struggle with loss of credibility and integrity.

This is not the place to explore the large volume of material in the New Testament which helps us to understand the true nature of the church by using rich and varied metaphors. One short remark will suffice: in Trinitarian approaches to ecclesiology, the most important of these metaphors are the church as the people of God, the family of the Father, the body of Christ, and the community of the Spirit. The question is: how could the church visibly embody God's people, the body of Christ, a community of the Spirit which it already is? How does the invisible become visible? It is only possible when the church itself lives with a deep consciousness of its own nature and its continual reformation to be what it already is.

The real crisis of the church is its inability to 'be church' sometimes not even conscious of what the church is or should be and sometimes deliberately ignoring it for personal gain. When the 'church' dilutes into mere human activity, it is not church anymore. No human effort will avert the deepening crisis if the church itself does not understand the real nature of the crisis and continually reform to be what it is. 


\section{Conclusion}

Crisis is part of the church's existence. A triumphant church which goes peacefully and majestically on its way is quite the opposite of what we read in the New Testament. Jesus died on a cross, not in a palace. When we follow Christ, it implies bearing a cross. Crisis and a real sense of our own inability are more fitting to the church than power and prosperity. Rudolf Bultmann (1955:38) speaks of crisis in eschatological terms: Christ's incarnation, his resurrection and the coming of God's kingdom precipitate crisis; people react in faith and disbelief. To what extent is the church able to participate in the coming of God's kingdom? Or is the crisis created by the kairos (Mk 1:15) unbearable?

To 'be church' requires a clear understanding of the essential nature, identity, calling and mission of the church - even though we know that the mystery of the church can never be adequately described (Küng 1976:27). Defining the church's nature will always be limited and preliminary and open to correction or revision. Like all theology, ecclesiology needs to understand its own limitations. That does not mean that we should not ask critical questions or that we should not experiment with new ideas. Critical and creative reflection on the nature and calling of the church to facilitate church reformation is of utmost importance.

In the process of reformation the creation and use of a new vocabulary is also important. It is an essential tool if we want to facilitate a contextual understanding of the church's nature and calling. Typical of such language would be less 'institution-speak' (with apologies to George Orwell) and more enthusiasm about a church who wants to be God's people, the family of the Father, the body of Christ and a community of the Holy Spirit.

Eventually it becomes a language of hope. When a church starts to tell stories of hope, of a renewed passion for the gospel and the church of the Triune God, the dynamics of a church can change completely. For centuries philosophers had been telling us that language creates reality; we are what we speak.

\section{Acknowledgements Competing interests}

The author declares that he has no financial or personal relationships which may have inappropriately influenced him in writing this article.

\section{References}

Barth, K., 1933, 'Für die Freiheit des Evangeliums', in Theologische Existenz Heute Heft 2, Chr. Kaizer Verlag, München.

Barth, K., 1936, Credo, Chr. Kaizer Verlag, Munich.
Barth, K., 1943, La Confession de Foi de l'Eglise, Delachaux \& Niestlé S.A., Neuchâtel.

Barth, K., 1947, Dogmatik im Grundriss im Anschluss an das apostolische Glaubensbekenntnis, W. Kohlhammer Verlag, Stuttgart.

Barth, K., 1967, Das Glaubensbekenntnis der Kirche, transl. H. Goes, EVZ-Verlag, Zürich.

Bosch, D.J. [1991] 2006, Transforming mission, 22nd edn., Orbis Books, New York.

Bultmann, R., 1955, Theology of the new testament volume two, SCM Press, London.

Busch, E., 1998, Die Grosse Leidenschaft. Einführung in die Theologie Karl Barths, Chr. Kaiser Gütersloher Verlaghaus, Gütersloh.

Busch, E., 2003, Credo. Das Apostolische Glaubensbekenntnis, Vandenhoeck \& Ruprecht, Göttingen.

Busch, E., 2004, The great passion: An introduction to Karl Barth's theology, transl. G.W. Bromley \& D.L. Guder (eds.), pp. 246-247, William B. Eerdmans Publishing Company, Grand Rapids.

De Groot, K., 2007, 'Onderzoek naar kerk in Nederland', in R. Brouwer (ed.), Levend Lichaam. Dynamiek van christelijke geloofsgemeenschappen in Nederland, pp. 27-45, Uitgeverij Kok, Kampen.

Drabble, M., 2001, 'A beastly century', American Scholar 70(1), 160.

Flannery, A., 1975, Vatican council II. The concilliar and post concilliar documents, Liturgical Press, Collegevile.

Frost, M. \& Hirsch, A., 2003, The shaping of things to come: Innovation and mission for the 21st-century Church, Hendrickson, Peabody.

Guder, D.L., 2000, The continuing conversion of the church, William B. Eerdmans Publishing Company, Grand Rapids.

Hauerwas, S., 2013, Approaching the end. Eschatalogical reflections on Church, politics and life, William B. Eerdmans Publishing Company, Grand Rapids.

Heitink, G. [1993] 2000, Praktische Theologie: Geschiedenis, Theorie, Handelingsvelden, 2nd edn., Uitgerverij Kok, Kampen.

Heitink, G., 2007, Een kerk met karakter: Tijd voor heroriëntatie, Uitgeverij Kok, Kampen.

Hirsch, A., 2006, The forgotten ways: Reactivating the missional church, Brazos, Grand Rapids.

Kärkkäinen, V.-M., 2002, An introduction to ecclesiology. Ecumenical, historical and global perspectives, InterVarsity Press, Downers Grove.

Kraemer, H., 1947, The Christian message in a non-Christian world, Edinburgh House Press, London.

Küng, H., 1976, The church, Search Press, London.

Küng, H., 1992, Credo: Das Apostolische Glaubensbekenntnis - Zeitgenossen erklärt, Piper, München \& Zürich.

Küng, H., 2003, The Catholic Church: A short history, transl. J. Bowden, The Modern Library, New York.

Leitenberg, M., 2006, 'Deaths in wars and conflicts in the 20th Century', in Cornell University Peace Studies Program Occasional Paper \#29, viewed 09 June 2014, from http://www.google.co.za/url?sa=t\&rct=j\&q=\&esrc=s\&source=web\&cd=5\&v from http://www.google.co.za/url?sa=t\&rct=j\&q=\&esrc=s\&source=web\&cd=5\&v
ed=0CEAQFjAE\&url=http\%3A\%2F\%2Fwww.cissm.umd.edu $\% 2 F$ papers $\% 2 F$ files $\% 2$ ed=0CEAQFjAE\&url=http\%3A\%2F\%2Fwww.cissm.umd.edu\%2Fpapers\%2Ffiles\%2 Fdeathswarsconflictsjune52006.pdf\&ei=KZmxU63oHMvY7AbRglG4
jCNFv8wzvRTSDsoS1WcaNd-bMZms81Q\&bvm=bv.69837884,d.ZGU

Mannion, G. \& Mudge, L.S., 2010, The Routledge companion to the Christian Church, Routledge, New York.

Niemandt, N., 2007, Nuwe drome in nuwe werklikhede. Geloofsgemeenskappe in pas met 'n postmoderne wêreld, Lux Verbi BM, Wellington.

Oberholzer, J.P., 1995, 'Die kerk', HTS Theological Studies 51(3), 851-857. http:// dx.doi.org/10.4102/hts.v51i3.1441

Oberholzer, J.P., 1999, 'Terug op die pad', in D.J.C. van Wyk (red.), 20ste Eeu hervormde teologie, pp. 449-462, Sentik, Pretoria.

Peterson, C.M., 2013, Who is the church? An Ecclesiology for the twenty-first century, Fortress Press, Minneapolis.

Rah, S.-C., 2009, The next Evangelicalism. Freeing the Church from western cultural captivity, InterVarsity Press, Downers Grove.

Randi, J., 1987, The faith healers, Prometheus Books, Buffalo.

Scaruffi, P., 2009, 'Wars and casualties of the 20th and 21st centuries', viewed 06 June 2014, from http://www.scaruffi.com/politics/massacre.html

Stewart, K., 2009, 'Keeping your pastor: An emerging challenge', Journal for the Liberal Arts and Science 13(3), 112-127.

Van't Spijker, W., 1990, 'Uitzicht', in W. Van't Spijker (red.), De Kerk. Wezen, weg en werk van die kerk naar reformatorisch opvatting, pp. 507-508, Uitgeverij De Groot Goudriaan, Kampen.

Volf, M., 1998, After our likeness: The Church as an image of the Tinity, William B. Eerdmans Publishing Company, Grand Rapids.

Ward, P., 2002, Liquid church, Paternoster Press, Carlisle. 